\title{
Purification and Properties of Skipjack Liver Tryptophan Hydroxylase
}

\author{
Takeshi Nagai, ${ }^{\dagger}$ Augusto E. Serrano, Jr., and Fumio Nagayama \\ Department of food Science and Technology, Tokyo University of Fisheries, Minato, Tokyo 108, Japan \\ (Received December 13, 1993)
}

Tryptophan hydroxylase (5-monooxygenase) (EC 1.14.16.4; Trp hydroxylase) in skipjack liver was extracted with Tris-acetate buffer solution and purified by acid treatment, ammonium sulfate fractionation, Sephadex G-150, DEAE-Sepharose CL-6B, Butyl-Sepharose 4B, and Toyopearl HW-55F chromatography. The enzyme was purified 1,500-fold with a $6.2 \%$ yield from skipjack liver. The apparent molecular weight was estimated to be 288,000 by gel filtration on Sephadex G-150. The enzyme gave a single protein band on sodium dodecyl sulfate-polyacrylamide gel electrophoresis which also revealed that the enzyme was composed of identical subunits with a molecular weight of 97,000 . The optimum temperature was $35^{\circ} \mathrm{C}$ and the enzyme was stable under $35^{\circ} \mathrm{C}$. The optimum $\mathrm{pH}$ was 8.0 and the enzyme retained more than $80 \%$ of its original activity between pH 7.5 and 8.5 after incubation at $35^{\circ} \mathrm{C}$ for $30 \mathrm{~min}$. The enzyme was inhibited by $\mathrm{Co}^{2+}, \mathrm{Mn}^{2+}$, and $\mathrm{Zn}^{2+}$ ions. However, it can be activated by adding $\mathrm{Fe}^{3+}, \mathrm{K}^{+}$, and $\mathrm{Li}^{+}$ions.

Key words: tryptophan hydroxylase, skipjack, SDS-PAGE, purification, properties

Tryptophan hydroxylase[L-Tryptophan, tetrahydropteridine: oxygen oxidoreductase (5-hydroxylating)] catalyzes the conversion of tryptophan to 5-hydroxytryptophan, which is the initial and rate-limiting step in the biosynthesis of the neurotransmitter serotonin $(5-\mathrm{HT}){ }^{1,2)}$ In addition, serotonin is converted to melatonin. In mammalia, serotonin is generally synthesized in the peripheral tissue and regulates the motor and perception system; sleeping, body temperature, appetite for food, sex behavior, secretion of growth hormone and prolactin, and so on. ${ }^{3)}$ Trp hydroxylase was first discovered in extracts of brain tissue, ${ }^{4)}$ and purified from rat brain stem and mouse mastocytoma. ${ }^{5,6)}$ In fish, it was found in liver ${ }^{7)}$ but has never been studied in the light of serotonin biosynthesis.

To clarify the mechanism of serotonin metabolism in fish, liver Trp hydroxylase from skipjack was purified and characterized in the present study.

\section{Materials and Methods}

Materials

Skipjack Katsuwonus pelamis were purchased from a fish market, and immediately transported to the laboratory. The liver was excised, and stored at $-80^{\circ} \mathrm{C}$ until use. Phenol reagent was purchased from Wako Pure Chemicals. D,L-6-Methyl-5,6,7,8-tetrahydropterine and 5-hydroxy-L-tryptophan were obtained from Sigma Chemical Co. Other reagents used were of analytical grade.

SDS-Polyacrylamide Gel Electrophoresis (SDS-PAGE)

SDS-PAGE was performed by the method of Laemmli et al. using $8 \%$ gel. $^{8)}$

Estimation of Molecular Weights

The molecular weight of purified Trp hydroxylase was estimated using Sephadex G-150 $(2.6 \times 90 \mathrm{~cm}$; eluted by $10 \mathrm{~mm}$ sodium phosphate buffer pH 7.0) gel filtration. Ferritin $(450,000)$, catalase $(240,000)$, aldolase
$(158,000)$, and albumin $(68,000)$ were used as standards.

\section{Determination of Protein Concentration}

Protein concentration was determined by the method of Lowry et al. as modified by Peterson using bovine serum albumin as standard. ${ }^{9,10}$

Assay of Enzyme Activity

The activity of Trp hydroxylase was assayed fluorometrically by measuring the formation of 5-hydroxy-L-tryptophan by the method of Friedman et al. ${ }^{11)}$ The assay mixture contained $0.05 \mathrm{~m} /$ of $1.0 \mathrm{mM}$ ferrous ammonium sulfate, $0.57 \mathrm{~m} /$ of $1.0 \mathrm{M}$ HEPES buffer $(\mathrm{pH} 7.6), 0.025 \mathrm{~m} l$ of $0.2 \mathrm{M} 2$-mercaptoethanol (2-ME), $0.025 \mathrm{~m} /$ of $20 \mathrm{mg} / \mathrm{m} l$ catalase, $0.05 \mathrm{ml}$ of $10 \mathrm{~mm}$ L-tryptophan, $0.05 \mathrm{~m} /$ of $5 \mathrm{mM}$ D, L-6-methyl-5,6,7,8-tetrahydropterine in $10 \mathrm{mM} \mathrm{HCl}, 0.38 \mathrm{ml}$ of $\mathrm{H}_{2} \mathrm{O}$, and $0.1 \mathrm{ml}$ of the enzyme preparation. The reaction was started by the addition of $\mathrm{D}, \mathrm{L}-6$-methyl$5,6,7,8$-tetrahydropterine. The reaction mixture was incubated at $35^{\circ} \mathrm{C}$ for $30 \mathrm{~min}$ with mild shaking. The reaction was stopped by the addition of $0.125 \mathrm{~m} /$ of $40 \%$ perchloric acid. After the precipitated protein was removed by centrifugation, a $1.0 \mathrm{~m} /$ aliquot of the supernatant was added to $1.5 \mathrm{ml}$ of $5 \mathrm{~N} \mathrm{HCl}$. The fluorescence of the solution was measured with the excitation wavelength set at $295 \mathrm{~nm}$ and the emission at $530 \mathrm{~nm}$. One unit of enzyme activity was defined as the activity which produces $1 \mathrm{nmol}$ of 5-hydroxy-L-tryptophan per min.

\section{Results and Discussion}

\section{Purification of Tryptophan Hydroxylase}

Liver samples were weighed and homogenized with 3 volumes of $50 \mathrm{~mm}$ Tris-acetate buffer ( $\mathrm{pH} 7.6$ ) containing $2 \mathrm{mM}$ phenylmethylsulfonyl fluoride (PMSF) and $4 \mathrm{~mm}$ 2-ME in a Potter-Elvehjem homogenizer with a motordriven Teflon pestle. The homogenate was then centrifuged at $100,000 \times g$ for $30 \mathrm{~min}$. The $\mathrm{pH}$ of the supernatant was brought to 4.8 by adding $50 \%$ acetic acid. After gentle stirring for $10 \mathrm{~min}$, the solution was centrifuged at $12,000 \times g$ for $10 \mathrm{~min}$. The pellet was dissolved in a minimal volume of $30 \mathrm{~mm}$ Tris- $\mathrm{HCl}$ buffer ( $\mathrm{pH} 8.5$ ). The enzyme solution was treated with solid ammonium sulfate and the precipitate

+ Present address: Department of Food Science and Technology, Shimonoseki University of Fisheries, Nagata-honmachi, Shimonoseki, Yamaguchi 759-65, Japan 
formed between $30-60 \%$ saturation was collected. The precipitate was dissolved in a minimal volume of $50 \mathrm{~mm}$ Tris-acetate ( $\mathrm{pH} 7.6$ ) containing $2 \mathrm{~mm}$ PMSF and $4 \mathrm{~mm}$ 2-ME and dialyzed overnight against $10 \mathrm{~mm}$ sodium phosphate buffer ( $\mathrm{pH} 7.0$ ) containing $10 \%$ glycerol and $50 \mu \mathrm{m}$ EDTA.

\section{Sephadex G-150 Column Chromatography}

The dialyzed enzyme was applied to a Sephadex G-150 column $(2.6 \times 90 \mathrm{~cm})$ and the dialysate was eluted with $10 \mathrm{~mm}$ sodium phosphate buffer $(\mathrm{pH} 7.0)$ containing $10 \%$ glycerol and $50 \mu \mathrm{M}$ EDTA at a flow rate of $0.5 \mathrm{~m} / / \mathrm{min}$. Fractions of $5 \mathrm{~m} l$ were collected.

\section{DEAE-Sepharose CL-6B Column Chromatography}

Fractions containing Trp hydroxylase activity were applied to a DEAE-Sepharose CL-6B column $(1.0 \times 5.0 \mathrm{~cm})$ which was pre-equilibrated with $10 \mathrm{~mm}$ sodium phosphate buffer ( $\mathrm{pH} 7.0$ ) containing 10\% glycerol and $50 \mu \mathrm{M}$ EDTA. The column was washed with the same buffer and the enzyme was eluted with a linear gradient of $0-1.0 \mathrm{M} \mathrm{NaCl}$ in the same buffer at a flow rate of $1.0 \mathrm{~m} / / \mathrm{min}$. Fractions of $5 \mathrm{~m} /$ were collected. After the sample was dialyzed against the same buffer, the enzyme solution was applied to a DEAE-Sepharose CL- $6 \mathrm{~B}(1.0 \times 5.0 \mathrm{~cm})$ which was previously equilibrated with $10 \mathrm{~mm}$ sodium phosphate buffer $(\mathrm{pH}$ 7.0) containing $10 \%$ glycerol and $50 \mu \mathrm{m}$ EDTA. The column was washed with the same buffer and the enzyme was eluted with a linear gradient of $0-0.5 \mathrm{M} \mathrm{NaCl}$ in the same buffer at a flow rate of $1.0 \mathrm{~m} l / \mathrm{min}$. Fractions of $5 \mathrm{~m} l$ were collected (Fig. 1).

\section{Butyl-Sepharose 4B Column Chromatography}

The sample collected from DEAE-Sepharpse CL-6B column chromatography was loaded onto a ButylSepharose $4 \mathrm{~B}$ column $(1.0 \times 4.0 \mathrm{~cm})$ previously equilibrated with $10 \mathrm{~mm}$ sodium phosphate $(\mathrm{pH} 7.0)$ containing $1.3 \mathrm{M}$ ammonium sulfate, $10 \%$ glycerol and $50 \mu \mathrm{m}$ EDTA. The column was washed with the same buffer, and the enzyme was eluted with a linear gradient of $1.3-0 \mathrm{M}$ ammonium sulfate in the same buffer at a flow rate of $1.0 \mathrm{ml} / \mathrm{min}$. Fractions of $3 \mathrm{ml}$ were collected (Fig. 1).

\section{Toyopearl HW-55F Column Chromatography}

After the sample was dialyzed against the same buffer, the enzyme solution was concentrated by ultrafiltration. The enzyme was further purified by applying it to a Toyopearl $\mathrm{HW}-55 \mathrm{~F}$ column $(1.9 \times 90 \mathrm{~cm})$ which was pre-equilibrated with $10 \mathrm{~mm}$ sodium phosphate $(\mathrm{pH} 7.0$ ) containing $10 \%$ glycerol and $50 \mu \mathrm{M}$ EDTA. The enzyme was eluted with the same buffer at a flow rate of $0.5 \mathrm{ml} / \mathrm{min}$. Fractions of $2.5 \mathrm{~m} l$ were collected (Fig. 1). A 1463-fold purification was achieved at this step. The purification of Trp hydroxylase

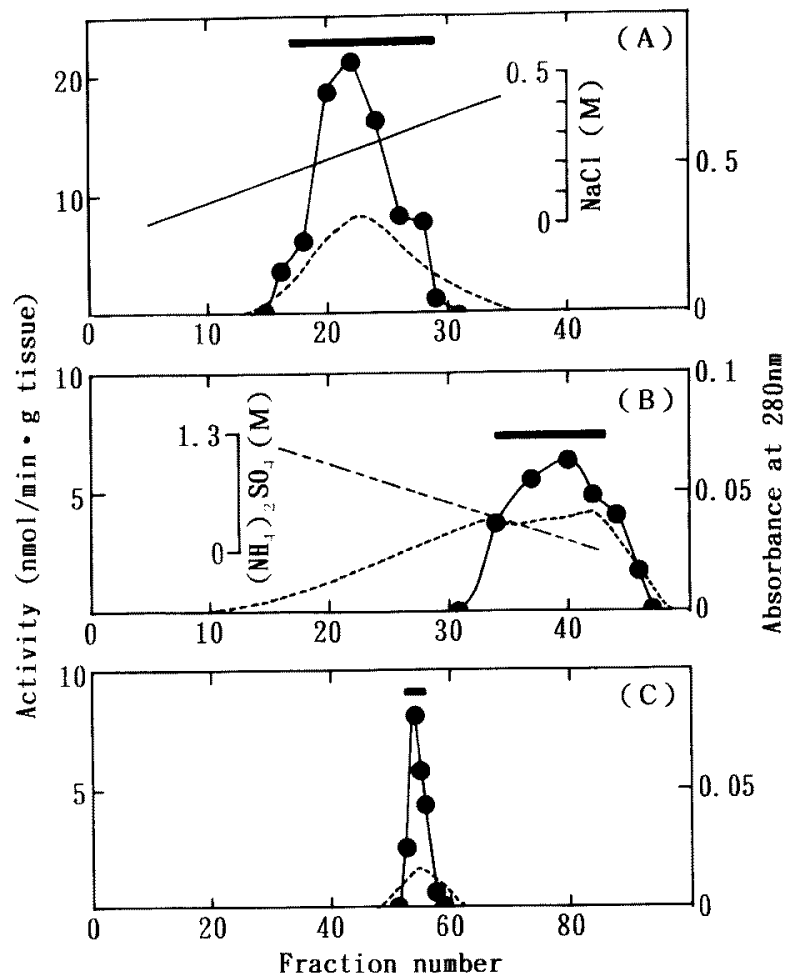

Fig. 1. Purification of tryptophan hydroxylase.

(A): 2nd DEAE-Sepharose CL-6B column chromatography. The enzyme solution $(49.4 \mathrm{mg}$ of protein) was put on a column $(1.0 \times 5.0 \mathrm{~cm})$ equilibrated with $10 \mathrm{~mm}$ sodium phosphate buffer, $\mathrm{pH}$ 7.0 , containing $10 \%$ glycerol and $50 \mu \mathrm{m}$ EDTA, and the enzyme was eluted with a linear gradient of $0-500 \mathrm{mM} \mathrm{NaCl}$ in the same buffer. Fraction volume, $5 \mathrm{ml}$. (B): Butyl-Sepharose 4B column chromatography of the DEAE-Sepharose CL-6B fraction. The enzyme solution $(5.1 \mathrm{mg}$ of protein) was put on a column $(1.0 \times 4.0 \mathrm{~cm})$ equilibrated with $10 \mathrm{~mm}$ sodium phosphate buffer, $\mathrm{pH} 7.0$, containing $1.3 \mathrm{M}$ ammonium sulfate, $10 \%$ glycerol and $50 \mu \mathrm{M}$ EDTA, and the enzyme was eluted with a linear gradient of $1.3-0 \mathrm{M}$ ammonium sulfate in the same buffer. Fraction volume, $3 \mathrm{~m} l$. (C): Gel-filtration of the Butyl-Sepharose $4 \mathrm{~B}$ fraction by a Toyopearl HW- $55 \mathrm{~F}$ column. The enzyme solution $(1.4 \mathrm{mg}$ of protein) was put on a column $(1.9 \times 90 \mathrm{~cm})$ equilibrated with $10 \mathrm{~mm}$ sodium phosphate buffer, $\mathrm{pH} 7.0$, containing $10 \%$ glycerol and $50 \mu \mathrm{M}$ EDTA, and the enzyme was eluted with the same buffer. Fraction volume, $2.5 \mathrm{ml} .(\ldots)$, Absorbance at $280 \mathrm{~nm}$; (-), enzyme activity; ( - ), $\mathrm{NaCl}$ concentration; (-.), ammonium sulfate concentration. Enzyme activity was measured by the method described in "Materials and Methods".

Table 1. Summary of the purification of skipjack liver tryptophan hydroxylase

\begin{tabular}{|c|c|c|c|c|c|}
\hline Fraction & $\begin{array}{l}\text { Total protein } \\
\text { (mg) }\end{array}$ & $\begin{array}{l}\text { Total activity } \\
\text { (units) }\end{array}$ & $\begin{array}{l}\text { Specific activity } \\
\text { (units/mg) }\end{array}$ & $\begin{array}{l}\text { Yield } \\
(\%)\end{array}$ & $\begin{array}{l}\text { Purification } \\
\text { (fold) }\end{array}$ \\
\hline Crude extract & 13,802 & 202 & 0.0146 & 100 & 1 \\
\hline Acid treatment & 3,025 & 50.1 & 0.0166 & 25 & 1.1 \\
\hline $30-60 \%\left(\mathrm{NH}_{4}\right)_{2} \mathrm{SO}_{4}$ & 935 & 58.7 & 0.0628 & 29 & 4.3 \\
\hline Sephadex G-150 & 261 & 20.1 & 0.0770 & 10 & 5.3 \\
\hline DEAE-Sepharose CL-6B (Ist) & 49.4 & 11.5 & 0.233 & 5.7 & 16.0 \\
\hline DEAE-Sepharose CL-6B (2nd) & 5.1 & 11.4 & 2.235 & 5.6 & 153 \\
\hline Butyl-Sepharose 4B & 1.4 & 8.9 & 6.357 & 4.4 & 435 \\
\hline Toyopearl HW-55F & 0.59 & 12.6 & 21.4 & 6.2 & 1,463 \\
\hline
\end{tabular}


is summarized in Table 1.

\section{Estimation of Molecular Weight}

As shown in Fig. 2, the molecular weight of the purified enzyme was estimated to be about 288,000 by gel filtration on Sephadex G-150. By SDS-PAGE, the purified enzyme appeared as a single protein band of molecular weight of about 97,000 in the presence or absence of a reducing reagent (Fig. 3). This value for skipjack liver Trp hydroxylase is similar to that for the enzymes from rat brain stem $^{5)}$ and mouse mastocytoma P815. ${ }^{6}$ ) For comparison, the purified rabbit hindbrain enzyme is a tetramer composed of two subunits (MW 57,500 and MW 60,000). ${ }^{12)}$ This value for skipjack liver Trp hydroxylase is different from that for the

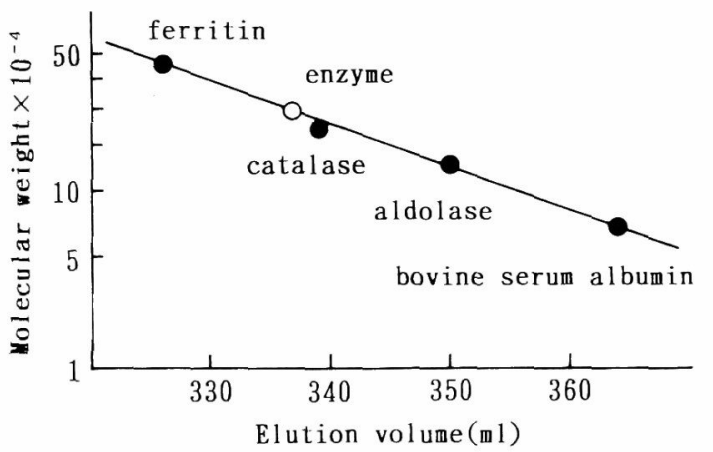

Fig. 2. Estimation of molecular weight of skipjack tryptophan hydroxylase by gel filtration on Sephadex G-150 column $(2.6 \times 90 \mathrm{~cm})$.

The enzyme was eluted with $10 \mathrm{~mm}$ sodium phosphate buffer $(\mathrm{pH}$ 7.0 ) containing $10 \%$ glycerol and $50 \mu \mathrm{M}$ EDTA. The standard proteins used are indicated.

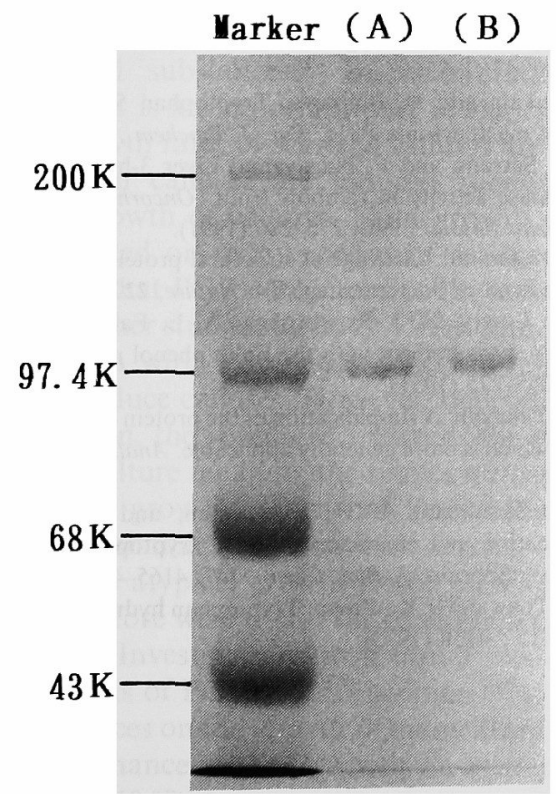

Fig. 3. SDS-PAGE analysis of the final preparation of skipjack liver tryptophan hydroxylase.

About $15 \mu \mathrm{g}$ of the purified enzyme was mixed with $20 \mu \mathrm{l}$ of $125 \mathrm{~mm}$ Tris- $\mathrm{HCl}$ buffer, $\mathrm{pH} 6.8$, containing 4\% SDS and $20 \%$ glycerol, and the mixture was heated at $100^{\circ} \mathrm{C}$ for $5 \mathrm{~min}$ in the presence of $10 \%$ 2-mercaptoethanol (A) or absence (B). The samples were applied to SDS-PAGE of $8 \% \mathrm{gel}$, and electrophoresis was done by the method of Laemmli et al. enzyme from rabbit hindbrain.

\section{Effect of $p H$}

The stability of purified skipjack liver Trp hydroxylase was investigated by using a buffer of various $\mathrm{pH}$ values. It is clear that the enzyme retained more than $80 \%$ of its original activity between $\mathrm{pH} 7.5$ and 8.5 after incubation at $35^{\circ} \mathrm{C}$ for $30 \mathrm{~min}$, but was unstable below $\mathrm{pH} 6.0$ or above pH 9.5 (Fig. 4).

The activity of the purified enzyme was determined for various $\mathrm{pH}$ conditions. The optimum $\mathrm{pH}$ of this enzyme was around 8.0 , which is similar to that for rat brain stem and mouse mastocytoma enzymes. ${ }^{5,6)}$

\section{Effect of Temperature}

The purified skipjack liver Trp hydroxylase in $0.456 \mathrm{M}$ HEPES buffer ( $\mathrm{pH} 7.6)$ was heated at $35,40,50,60$, and $70^{\circ} \mathrm{C}$ for $10,20,30$, and $60 \mathrm{~min}$. After cooling, the residual catalytic activity was assayed (Fig. 4). It is clear that the enzyme was unstable beyond $35^{\circ} \mathrm{C}$, but was stable when stored at $-80^{\circ} \mathrm{C}$, and lost almost none of its activity within 2 days at $4^{\circ} \mathrm{C}$. By comparison, the purified mastocytoma Trp hydroxylase lost almost all its activity within $20 \mathrm{~h}$ at $4{ }^{\circ} \mathrm{C}$ without stabilizing agents but became stable with the addition of a nonionic detergent, EDTA and ethylene
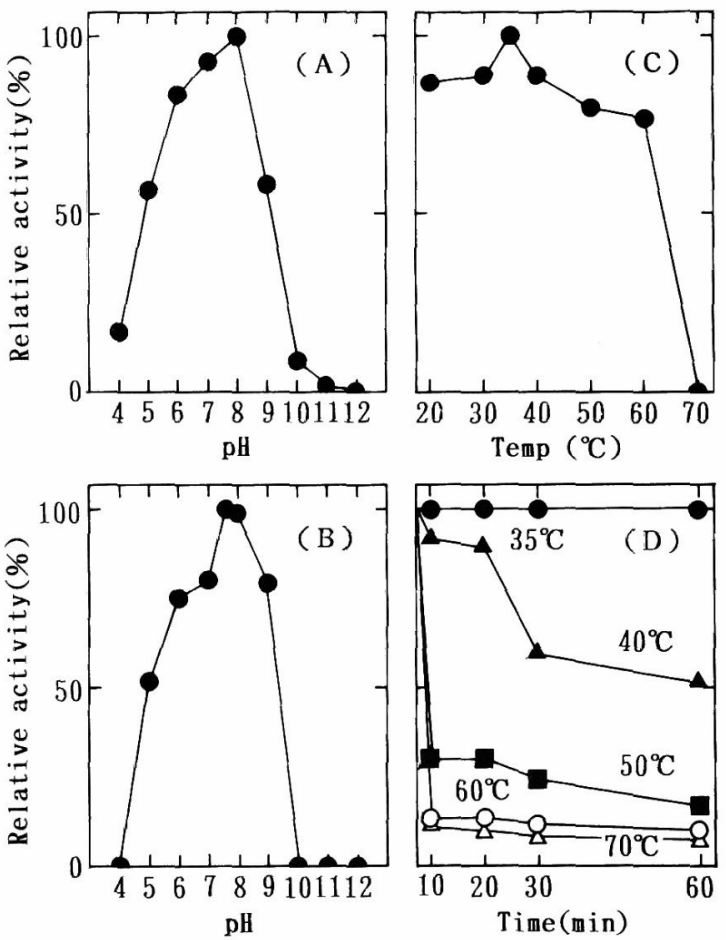

Fig. 4. Effect of $\mathrm{pH}$ and temperature on skipjack liver tryptophan hydroxylase activity.

(A): The enzyme activity was measured over a $\mathrm{pH}$ range from $4.0-12.0$ in $20 \mathrm{~mm}$ Britton-Robinson buffer. (B): The enzyme was incubated in $20 \mathrm{~mm}$ Britton-Robinson buffer of various $\mathrm{pH}$ values at $4^{\circ} \mathrm{C}$ for $60 \mathrm{~min}$, then the $\mathrm{pH}$ was adjusted to the optimum, and the residual activity was assayed under the standard conditions. (C): The enzyme activity was assayed under the standard conditions except that the temperature was varied as indicated. (D): The enzyme was incubated for $30 \mathrm{~min}$ at various temperatures as indicated. After incubation, the tubes were placed in ice and then assayed for residual activity under the standard conditions. 


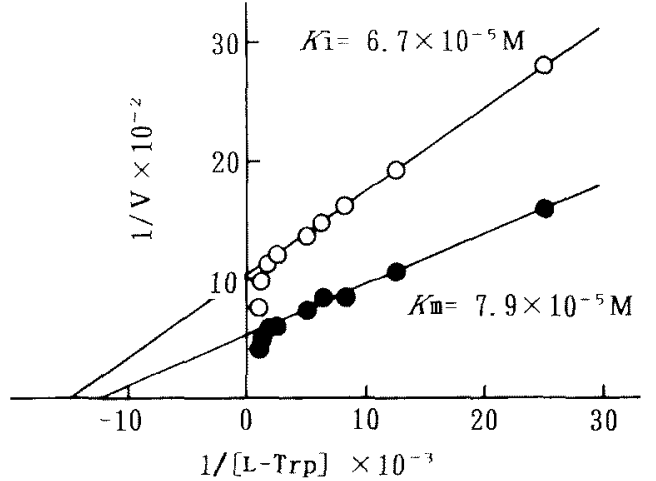

Fig. 5. Lineweaver-Burk plot of skipjack liver tryptophan hydroxylase activity for L-tryptophan.

(O), non PCPA; $(O)$, in PCPA.

Table 2. Effect of various reagents on the activity of tryptophan hydroxylase from skipjack liver

\begin{tabular}{lc}
\hline $\begin{array}{c}\text { Reagents } \\
(1 \mathrm{mM})\end{array}$ & $\begin{array}{c}\text { Relative activity } \\
(\%)\end{array}$ \\
\hline $\mathrm{None}$ & 100 \\
$\mathrm{KCl}$ & 101 \\
$\mathrm{NaCl}$ & 97 \\
$\mathrm{LiCl}$ & 104 \\
$\mathrm{HgCl}_{2}$ & 59 \\
$\mathrm{MgCl}_{2}$ & 97 \\
$\mathrm{BaCl}_{2}$ & 90 \\
$\mathrm{ZnSO}_{4}$ & 2 \\
$\mathrm{MnCl}_{2}$ & 0 \\
$\mathrm{CuSO}_{4}$ & 49 \\
$\mathrm{CaCl}_{2}$ & 17 \\
$\mathrm{CoCl}_{2}$ & 0 \\
$\mathrm{FeCl}_{3}$ & 105 \\
$\mathrm{CH}_{2} \mathrm{ICOOH}^{* 1}$ & 116 \\
$\mathrm{PCMB}^{* 1}$ & 118 \\
$\mathrm{DTNB}^{* 2}$ & 95 \\
$\mathrm{Glutathione}$ & 88
\end{tabular}

*1: PCMB: p-chloromercuribenzoic acid.

*2: DTNB: 5,5'-dithiobis(2-nitrobenzoic acid).

glycol. ${ }^{6)}$ The optimum temperature of this enzyme was $35^{\circ} \mathrm{C}$ (Fig. 4)

\section{$K_{\mathrm{m}}$ for L-Tryptophan}

From the Lineweaver-Burk plot of the enzyme, the $K_{\mathrm{m}}$ value for L-tryptophan was estimated to be $7.9 \times 10^{-5} \mathrm{M}$ (Fig. 5). This value agrees with that obtained for rat brain stem and mouse mastocytoma. ${ }^{5,6}$

\section{$K_{\mathrm{i}}$ for $\mathrm{D}, \mathrm{L}-p$-Chlorophenylalanine $(P C P A)$}

$\mathrm{D}, \mathrm{L}-p$-Chlorophenylalanine is a competitive inhibitor and the $K_{\mathrm{i}}$ for this was computed to be $6.7 \times 10^{-5} \mathrm{M}$ from the Lineweaver-Burk plot of the enzyme (Fig. 5). This value is similar to that of mouse mastocytoma enzyme, $2.6 \times$ $10^{-5} \mathrm{M},{ }^{6}$ ) and pineal enzyme, $2.0 \times 10^{-5} \mathrm{M}$, but different from that of the brain enzyme, $30.0 \times 10^{-5} \mathrm{M}$.

\section{Effect of Metal lons and SH-Blocking Reagents}

The effects of various metal ions ( $1 \mathrm{~mm}$ ) on enzyme activity are shown in Table 2 . The enzyme was strongly inhibited by $\mathrm{Co}^{2+}, \mathrm{Mn}^{2+}$, and $\mathrm{Zn}^{2+}$, but was slightly activated by $\mathrm{Fe}^{3+}, \mathrm{K}^{+}$, and $\mathrm{Li}^{+}$. The activity of the enzyme was not affected by the SH-blocking reagents. These results suggest that the skipjack liver enzyme was not SH-enzyme. It has been reported that the activity of the mouse mastocytoma enzyme increased approximately five-fold by preincubation with dithiothreitol and $\mathrm{Fe}^{2 \dagger}$, 6) but the skipjack liver enzyme did not increase by preincubation with dithiothreitol.

Acknowledgments This study was supported in part by a Grant-in-Aid for Scientific Research from the Ministry of Education, Science, and Culture of Japan

\section{References}

1) D. G. Grahame-Smith: Tryptophan hydroxylase in brain. Biochem. Biophys. Res. Commun., 16, 586-592 (1964).

2) E. Jequier, W. Lovenberg, and A. Sjoerdsma: Tryptophan hydroxylase inhibition; the mechanism by which $p$-chlorophenylalanine depletes rat brain serotonin. Mol. Pharmacol., 3, 274-278 (1967).

3) C. Tanaka and M. Kimura: Neurotransmitters (ed. by G. Takagaki and T. Nagatsu), Kodansha, Tokyo, 1984, pp. 156-191.

4) W. Lovenberg, E. Jequier, and A. Sjoerdsma: Tryptophan hydroxylation; measurement in pineal gland, brain stem, and carcinoid tumor. Science, 155, 217-219 (1967).

5) H. Nakata and H. Fujisawa: Purification and properties of tryptophan 5-monooxygenase from rat brain-stem. Eur. J. Biochem., 122, $41-47$ (1982).

6) H. Nakata and H. Fujisawa: Tryptophan 5-monooxygenase from mouse mastocytoma P815. Eur. J. Biochem., 124, 595-601 (1982).

7) A. E. Serrano and F. Nagayama: Liver 3-hydroxyanthranilic acid oxygenase activity in rainbow trout (Oncorhynchus mykiss). Comp. Biochem. Physiol., 99B, 275-280 (1991).

8) U. K. Laemmli: Cleavage of structural proteins during the assembly of the head of bacteriophage T4. Nature, 227, 680-685 (1970).

9) O. H. Lowry, N. J. Rosebrough, A. L. Farr, and R. J. Randail: Protein measurement with the Folin phenol reagent. J. Biol. Chem., 193, 265-275 (1951).

10) G. L. Peterson: A simplification of the protein assay method of Lowry et al. which is more generally applicable. Anal. Biochem., 83, 346-356 (1977)

11) P. A. Friedman, A. H. Kappelman, and S. Kaufman: Partial purification and characterization of tryptophan hydroxylase from rabbit hindbrain. J. Biol. Chem., 247, 4165-4173 (1972).

12) J. H. Tong and S. Kaufman: Tryptophan hydroxylase. J. Biol. Chem. 250, $4152-4158(1975)$ 